DID UNILATERAL DIVORCE LAWS RAISE DIVORCE RATES?

A RECONCILIATION AND NEW RESULTS

Justin Wolfers

Working Paper 10014 
NBER WORKING PAPER SERIES

\title{
DID UNILATERAL DIVORCE LAWS RAISE DIVORCE RATES? A RECONCILIATION AND NEW RESULTS
}

\author{
Justin Wolfers \\ Working Paper 10014 \\ http://www.nber.org/papers/w10014 \\ NATIONAL BUREAU OF ECONOMIC RESEARCH \\ 1050 Massachusetts Avenue \\ Cambridge, MA 02138 \\ October 2003
}

Thanks to Leora Friedberg and Jon Gruber for sharing their data and for very fruitful discussions. Eric Klotch provided outstanding research assistance. This paper has also benefited from useful conversations with David Ellwood, Frank Furstenberg, Caroline Hoxby, Christopher Jencks, Larry Katz, Eric Rasmussen and Betsey Stevenson, as well as the input of participants in the Harvard Labor Lunch, and seminar participants at Harvard, Berkeley, Michigan, Stanford and Yale. The views expressed herein are those of the authors and are not necessarily those of the National Bureau of Economic Research.

(C)2003 by Justin Wolfers. All rights reserved. Short sections of text, not to exceed two paragraphs, may be quoted without explicit permission provided that full credit, including (C) notice, is given to the source. 
Did Unilateral Divorce Laws Raise Divorce Rates? A Reconciliation and New Results Justin Wolfers

NBER Working Paper No. 10014

October 2003

JEL No. J12, J16, J18, I3, J1, K3, C23, D13, D23, N32, R2

\begin{abstract}
$\underline{\text { ABSTRACT }}$
Application of the Coase Theorem to marital bargaining suggests that shifting from a consent divorce regime to no-fault unilateral divorce laws should not affect divorce rates. Each iteration of the empirical literature examining the evolution of divorce rates across US states has yielded different conclusions about the effects of divorce law liberalization. I show that these results reflect a failure to jointly consider both the political endogeneity of these divorce laws and the dynamic response of divorce rates to a shock to the political regime. Taking explicit account of the dynamic response of divorce rates to the policy shock, I find that liberalized divorce laws caused a discernible rise in divorce rates for about a decade, but that this increase was substantially reversed over the next decade. That said, this increase explains very little of the rise in the divorce rate over the past half century. Both administrative data on the flow of new divorces, and measures of the stock of divorcees from the census support this conclusion. These results are suggestive of spouses bargaining within marriage, with an eye to their partner's divorce threat.

Justin Wolfers

Graduate School of Business

Stanford University

518 Memorial Way

Stanford, CA 94305

and NBER

jwolfers@stanford.edu
\end{abstract}




\section{Introduction}

The "no-fault revolution" that swept the United States through the 1970s radically altered the parameters of family law. The new no-fault unilateral divorce laws allowed people to seek a divorce without the consent of their spouse, a dramatic departure from previous practice. This decade also saw radical changes in the structure of American families, with divorce rates rising dramatically across the nation. Are these two trends connected? This question has been argued at length, and each iteration of the debate has yielded new insights. Peters (1986) argued that divorce rates were unaffected by the change in legal regime, a finding rebutted by Allen (1992), and subsequently countered by Peters (1992). Parallel literatures in both sociology and law have also yielded fierce debate. ${ }^{1}$ Practitioners also seem divided: a recent survey of members of the Family Law Section of the American Bar Association found that around two-thirds of respondents do not agree that there is a direct correlation between higher divorce rates and divorce law liberalization (Gatland (1997)).

Friedberg (1998) presented a seemingly appealing alternative to earlier studies. Her paper analyzed comprehensive administrative divorce data in a state-based panel. In response to concerns about the endogeneity of divorce reform expressed in the Peters-Allen exchange (divorce reform came first to those states with historically high divorce rates), Friedberg included state and year fixed effects, as well as state-specific time trends in her specification. Friedberg interprets her results as suggesting that the adoption of unilateral divorce laws accounts for about one-sixth of the rise in the divorce rate since the late 1960 s, a finding that has since been widely accepted. ${ }^{2}$

This paper argues that these conclusions are somewhat misleading. A major difficulty in difference-in-difference analyses involves separating out pre-existing trends from the dynamic response of a policy shock. Her approach appears to confound the two. Slight modifications to Friedberg's procedures yield more directly interpretable estimates.

I find that the divorce rate rose sharply following the adoption of unilateral divorce laws, but that this rise was reversed within about a decade. There is no evidence that this rise in divorce is persistent. Indeed, some of my results suggest - somewhat puzzlingly - that 15 years after reform, the divorce rate is lower as a result of the adoption of unilateral divorce.

The fundamental theoretical issue at stake in this empirical debate is the applicability of the Coase Theorem to marital relations. Becker (1981) argues that unilateral divorce simply reassigns existing property rights between spouses. Under the consent divorce regime, both partners must agree to a divorce,

\footnotetext{
${ }^{1}$ Related contributions in the economics literature include: Gruber (2000), Johnson and Mazingo (2000) and Mechoulan (2001). In the Law and Economics literature see: Brinig and Buckley (1998), Ellman and Lohr (1998), and Ellman (2000), and in the sociology literature: Nakonezny, Shull and Rodgers (1995), Glenn (1997), Rodgers, Nakonezny and Shull (1997), Glenn (1999) and Rogers, Nakonezny and Shull (1999).

${ }^{2}$ See Binner and Dnes (2001), Gruber (2000), Johnson and Mazingo (2000), Rowthorn (1999).
} 
whereas the unilateral regime only requires one spouse to desire a divorce. In Coasian terms, why should a reassignment of property rights - from the happily married spouse to their partner who would prefer a divorce - change outcomes? Peters (1986) and Stevenson and Wolfers (2003) discuss plausible reasons for the failure of the Coase theorem in marital bargaining. In this paper my focus is primarily empirical, and I seek to evaluate whether divorce rates rose following the passage of unilateral divorce laws.

In section one I present Friedberg's results, and show that her estimates are replicable. Working through a simple example, section two shows that in applications involving interesting dynamics, the standard difference-in-difference approach may produce misleading results if panel-specific trends are included as controls. This is a more general problem in differences-in-differences analyses, and one contribution of this paper is simply to highlight the bias that might result. Imposing minimal structure on the dynamic response of the divorce rate, I present a well-identified specification that suggests that divorce rates rose temporarily following the adoption of unilateral divorce laws. These results are not particularly sensitive to the inclusion of state-specific trends, and there is little evidence of a persistent impact. Section three finds complementary evidence in census data tracing the evolution of the stock of ever-divorced people; section four explores the empirical robustness of my findings, and section five turns to interpretation.

\section{Replicating Friedberg (1998)}

Between 1968 and 1988, 29 states changed their legal systems from some variant of consent divorce, to a unilateral system. Standard accounts of this period of legislative activity suggest that the timing of these changes was plausibly exogenous (see Jacob, 1988). Thus, state-based panel estimation of the effects of these changes seems natural. Friedberg collected administrative data on the divorce rate in each state and year from 1968 to 1988 from Vital Statistics of the United States. The divorce rate is defined as the annual number of new divorces per thousand people in each state. These data cover virtually every divorce in the US throughout this period. She estimated: ${ }^{3}$

$$
\begin{gathered}
\text { Divorce Rate }_{s, t}=\beta \text { Unilateral }_{s, t}+\sum_{s} \text { State fixed effect }_{s}+\sum_{t} \text { Time fixed effects } \\
\\
{\left[+\sum_{s} \text { State }_{s} * \text { Time }_{t}+\sum_{s} \text { State }_{s} * \text { Time }_{t}^{2}\right]+\varepsilon_{s, t}}
\end{gathered}
$$

The variable Unilateral is a dummy, set equal to one when the state has a unilateral divorce regime, and zero under a consent divorce regime. The coefficient $\beta$ is interpreted as the average rise in the divorce rate attributable to the legal change. Much of the earlier debate in this literature focussed on

\footnotetext{
${ }^{3}$ A range of indicator variables was also included to account for slight breaks in the various state divorce series. These have no important effect on estimated results, and hence while I include them in the replication in Table 1, for simplicity, I drop them in all subsequent analysis.
} 
coding these legal changes. ${ }^{4}$ More precisely, this involved two debates - which reforms are of substantive interest, and how to appropriately code up the law. On the former, I follow Friedberg in focusing on the assignment of property rights between spouses (the distinction between unilateral and consent divorce), while on the latter, I take Friedberg's coding as a starting point, but show that the main findings are robust to a range of different coding regimes.

Equation (1) is estimated using population-weighted least squares. Panel A of Table 1 simply reprints Friedberg's results. The specification shown in column one includes state and year fixed effects, yielding reasonably precisely estimated coefficients suggesting almost no change in the divorce rate. This finding is consonant with Peters $(1986,1992)$, who found that when one controls for pre-existing differences in state divorce propensities, unilateral divorce laws did not affect divorce rates.

However, Friedberg argues (p.611) that even this may be too restrictive of a specification, and that "the factors which influence divorce may vary within a state over time, confounding the estimates of the state effects... Including state-specific trends allows unobserved state divorce propensities to trend linearly and even quadratically over time and reveals that unilateral divorce raised divorce rates significantly and strongly." Of course, these omitted factors bias the estimated effect of unilateral divorce laws only if they are correlated with divorce laws. Column two shows Friedberg's preferred specification, which includes state-specific linear time trends to account for slow-moving social and demographic trends in each state. This specification changes the point estimate dramatically, suggesting that the divorce rate rose by 0.447 . Comparing this coefficient with an average rate of 4.6 divorces per thousand people per year, this translates to a rise of a little under $10 \%$. Testing for robustness, Friedberg adds state-specific quadratic time trends in column 3, finding a similar effect. Thus, she concludes that unilateral divorce caused the divorce rate to rise significantly. In later tables, she includes leads and lags of the independent variable, and concludes (p.608) that "the effect of unilateral divorce on divorce behavior was permanent, not temporary."

Panel B of Table 1 shows my attempts to replicate Friedberg's results. Replication was relatively simple because Friedberg generously shared her divorce data. In all columns the results are extremely similar. Remaining differences are in the second decimal place, and presumably reflect revised population estimates that are used as weights, or differences in computational procedures. Beyond the statistics shown in Panel B, my regressions also closely replicated detail on state and year effects provided in the appendices of Friedberg's paper. This seems to be as close to a complete replication as one can hope for. ${ }^{5}$

\footnotetext{
${ }^{4}$ In the economics literature see the Peters-Allen exchange; in law and economics, see the dialogue between Brinig and Buckley and Ellman and Lohr.

${ }^{5}$ On computational procedures, see McCullough and Vinod (1999). Regarding replication, see Dewald et. al. (1986).
} 
A worrying feature of the estimates in Table 1 is their sensitivity to the inclusion of state-specific trends. Friedberg's interpretation is that these trends reflect omitted variables, and thus their inclusion remedies an omitted variable bias. However, the omission of these variables should only bias these coefficients if there is a systematic relationship between the trend in divorce rates and the adoption of unilateral divorce laws. Certainly such a relationship seems at odds with the purported exogeneity of the timing of the adoption of these laws. Further, controlling for state time trends raises the coefficient on Unilateral, a finding that can be reconciled with an omitted variables interpretation only if factors correlated with a relative fall in divorce propensities led states to adopt unilateral divorce laws. This seems unlikely; if anything, one might expect factors associated with a rising divorce rate to have increased the pressure for reform.

Chart 1 shows the evolution of the average divorce rate across the reform and control states, respectively. ${ }^{6}$ Clearly higher divorce rates in reform states have been a feature since at least the mid1950 s, undermining any inference that these cross-state differences reflect the "no-fault revolution" of the early 1970s. ${ }^{7}$ Thus controlling for these pre-existing differences - perhaps through the inclusion of state fixed effects - seems important (a point made by both Peters (1986) and Friedberg (1998)). The dashed line shows the evolution of the difference in the divorce rate between reform and control states. This line allows a coarse comparison of the relative pre-existing trends; if anything, it shows a mildly rising trend in the divorce rate in treatment states relative to the control states prior to reform, suggesting that adding controls for pre-existing trends should reduce the Unilateral coefficient.

The next section reconciles these findings. In the context of a simple example highlighting stockflow dynamics, I show that Friedberg's results are not robust to plausible specifications of the dynamic effects of changes in divorce laws. Specifically, it appears that her estimates confound pre-existing trends with the response of the divorce rate to the policy shock. More plausible specifications suggest that the divorce rate rose for a number of years following divorce law reform; no effect is discernible after a decade, and there is some evidence of a reversal over the ensuing period.

\section{Stock-flow Dynamics and Difference-in-Difference Estimates}

A shift in divorce regimes is likely to have very different short run and long run effects. Immediately following reform, the divorce rate is likely to rise dramatically as the courts cater to pent-up demand for the new type of divorce facilitated by this change. Evolving norms, and the slow diffusion of information about the divorce regime may keep the divorce rate high for a period. This may be further reinforced by developments in a thicker remarriage market. Eventually this "pent-up demand" will run its course, and

\footnotetext{
${ }^{6}$ Controls are defined as those states that did not change their divorce laws during Friedberg's 1968-88 sample.

${ }^{7}$ See Allen (1992) and Johnson and Mazingo (2000) for papers that are identified off cross-state variation in divorce rates and divorce hazards, respectively.
} 
the flow of divorces will drop back toward its new steady state. Further interesting dynamic patterns may be evident in the medium run: bad matches may be dissolved earlier, shifting the pattern of divorce across the life-cycle, differential selection into marriage will change the nature of the "at-risk" population, and so on. During the transition to the new steady state, it is likely that the corresponding stock variable - the ever-divorced population - will slowly approach its new level. However, during the transition to this new steady state, the flow of new divorces will not necessarily bear a simple relation to either its new steadystate level, or to the ever-divorced population.

This section shows that standard difference-in-difference estimates confound these stock-flow dynamics with panel-specific trends, yielding results that are difficult to interpret. A simple example provides intuition. Suppose that each year $\alpha \%$ of couples reassess their relationship and decide whether or not to divorce, given the current legal regime. Under consent divorce, the $c \%$ most incompatible marriages will dissolve; unilateral divorce laws lead a further $\varepsilon \%$ to divorce. Further, the stock of everdivorced people depreciates at the rate $\delta$, as divorcees die and are replaced by newborns. Chart 2 shows the resulting adjustment process for a set of plausible parameters $(\alpha=20 \%, c=20 \%, \varepsilon=0.4 \%, \delta=2.5 \%)$. Note that even a very small value of $\varepsilon$ yields a large spike in the flow of new divorces. (These dynamics are analogous to the response of investment to policy shocks that affect the desired capital stock - under a partial adjustment model.)

Empirically, my approach will simply trace out the full adjustment path. Note that Friedberg's preferred specification includes only the single Unilateral dummy to capture the full adjustment process. Because the dynamics are not well captured by this single variable, state-specific trends pick up not only different pre-existing trends across states, but also differences in the evolution of the divorce rate between reform and control states subsequent to the adoption of unilateral divorce laws. Chart 2 illustrates.

The bold line shows the hypothetical divorce rate. The fitted time trend is shown in gray. Friedberg's equation effectively partials this out, and the residuals are shown as the dashed line. The Unilateral coefficient compares the average difference between the divorce rate and the trend before and after the legal change. Thus, her regression compares the line segments titled "Before" and "After". This difference is several times larger than the true effect evident in the bold line.

This critique applies beyond this specific stylized example - any dynamics beyond a discrete series break are not fully accounted for by the simple Unilateral dummy, leading the state-specific trend "controls" to partly reflect the dynamic response of the response variable to the policy shock. Thus the estimated Unilateral dummy reflects the difference between the actual path of divorces and a systematically biased estimate of its counterfactual. Including state-specific quadratic time trends might either exacerbate or ameliorate this bias, depending on the specific dynamic response. It is worth noting that it is not unusual in the labor literature to simply add panel-specific trends in this manner as a "check". 
These problems are exacerbated when there only a few observations are available before the policy shock. Friedberg's sample begins in 1968, while the wave of divorce reform followed fairly immediately, leaving only a couple of observations with which to identify pre-existing state trends.

To resolve these problems I extend Friedberg's sample back to 1956 (so as to allow for a credible identification of pre-existing state-specific trends), ${ }^{8}$ and add variables that model the dynamic response of divorce quite explicitly. I pursue a specification that imposes very little structure on the response dynamics, including dummy variables for the first two years of the new legal regime, for years three and four, five and six and so on. Thus, these variables should identify the entire response function allowing the estimated state-specific time trends to identify pre-existing trends. ${ }^{9}$

Table 2 shows my preferred set of estimates, running equation (2) on an unbalanced panel of divorce rates from 1956-88:

$$
\begin{aligned}
\text { Divorce Rate }_{s, t}= & \sum_{k \geq 1} \beta_{k} \text { Unilateral divorce has been in effect for } k \text { periods }_{s, t}+\sum_{s} \text { State fixed effects }_{s}+\sum_{t} \text { Time fixed effects }_{t} \\
& {\left[+\sum_{s} \text { State }_{s} * \text { Time }_{t}\right]+\varepsilon_{s, t} }
\end{aligned}
$$

The first column of Table 2 reports results from a specification including only state and year fixed effects as controls; the second adds state-specific time trends, and the third also includes quadratic statespecific time trends. Chart 3 shows the results graphically. All three specifications suggest that the divorce rates spiked immediately following the adoption of unilateral divorce laws. This effect declines over the ensuing decade, and the dynamic response is remarkably similar to that shown in the stylized example discussed above. A decade later, it is difficult to find any effects of divorce reform. Intriguingly, the estimated coefficients become significantly negative after a little more than a decade in two specifications. The conclusion that divorce rose noticeably over the decade following reform appears quite robust. Evidence for a negative effect over the ensuing period is more fragile.

The fragility of the long-run estimates is a recurring theme throughout my robustness testing. For example, Chart 4 shows the results of similar regressions when analyzing several alternative taxonomies of family law regimes. The lack of precision in these estimates cautions against attempts to parse out a family of estimates corresponding to a more fine-grained coding of family law regimes.

Reconciling my results with Friedberg's is fairly simple, and California provides an illustrative example. The top panel of Chart 5 shows California's divorce rate after controlling for state and year fixed effects. The divorce rate clearly spikes following the 1970 reform, returns to its previous level by about 1980, and then drops to a lower level for the ensuing decade.

\footnotetext{
${ }^{8}$ Before 1956, the divorce data by state are rather patchy. Appendix A shows that my longer sample does not much change Friedberg's estimates. Thus, to the extent that our estimates diverge, differences in identification approaches, rather than differences in samples are the cause.

${ }^{9}$ Friedberg analyzed the effects in the first two years, although her estimates - reflecting the identification problems discussed above -suggest that the effects of unilateral divorce laws were smaller in their first two years.
} 
Friedberg focuses only on the shorter sample: 1968-88 (highlighted in gray). Thus, the specification including only state and year fixed effects effectively compares the observations for 19681969 with those from 1970 onward. As can be seen, the average level of the divorce rate from 1970-1988 is fairly similar to that in the late 1960s (it is higher for a decade, and then lower for a decade), leading to the conclusion that the average effect throughout the period was zero. Indeed, recall that the results in column one of Tables 1 and 2 yielded estimates for the US close to zero.

Friedberg finds a significant effect of divorce reform only when she adds state-specific trends (as in columns two and three in Table 1). To see why, note that her regression fits a strongly decreasing trend to California (the dashed gray line) - despite the fact that the pre-existing trend appears to be - if anything - slightly increasing. The gray line in the lower panel shows the residual variation identifying Friedberg's specification. By subtracting a decreasing trend, Friedberg is led to conclude that the divorce rate rose dramatically following the adoption of unilateral divorce laws, and that this effect persisted for twenty years. The thin line shows the residual variation identifying my regression (column two of Table 2). As one would expect from a casual inspection, there is not much of a pre-existing trend, and thus adding controls for state-specific trends does not much change my estimates.

These mis-identified state-specific trends are a ubiquitous problem in Friedberg's specification, even when allowing for a longer pre-intervention sample. To provide a point of comparison, I estimated both my specification and Friedberg's over the complete 1956-88 sample, controlling for state-specific time trends. Chart 5 plots my estimate of each state's time trend against that estimated from Friedberg's specification; the 29 states that changed their laws are marked with a cross, while the remaining 21 "control" states are shown with circles. The single Unilateral variable in Friedberg's specification picks up a shift in the level of the divorce rates following the reform, but leaves the subsequent downward trend following the initial post-reform spike in divorces to be picked up by state-specific trends. Thus we see that her specification systematically estimates a more negative state-specific time trend in reform states. It is only when measured against this counterfactual of relatively falling divorce rates in reform states, that Friedberg finds large and persistent effects of divorce laws on the divorce rate.

\section{Implications for the Stock of Marriages: Census Data}

Naturally these results on the flow of new divorces have testable implications for data on the stock of divorcees, and hence I turn to analyzing census data. I start by analyzing a specification suggested by Gruber (2000), focusing on census data from 1960-1990. Gruber analyzes state-year-age-sex cells, finding that the proportion of the population that is divorced at a point in time rises by about 1 percentage point (or 12\%) following the adoption of unilateral divorce laws. That is, Gruber ran:

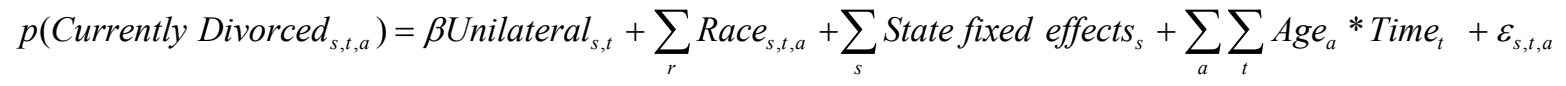


The first column of Table 3 reprints Gruber's results. ${ }^{10}$ As can be seen, the probability of being divorced on census day rose by around one percentage point following the adoption of unilateral divorce laws. While I was able to reconstruct these estimates from aggregate data provided to me by Gruber, I was not able to completely reconstruct these aggregate data from original IPUMS sources. ${ }^{11}$ That said, remaining differences are extremely minor, and column two shows the corresponding estimates from my data yields very similar results. ${ }^{12}$

Unfortunately, these data describe those who are divorced at a point in time, while the majority of divorcees later remarry, and hence their divorces are not measured in these numbers. Indeed, data from the June 1995 CPS Marital History supplement reveal that of the female population aged 25-50, only 49\% of the ever divorced population are to be found in the currently divorced pool; a further $47 \%$ have remarried, $3 \%$ have remarried and are separated, while $1 \%$ have remarried and been widowed.

By exploiting data on the number of times each respondent has been married, I construct a measure of the ever-divorced population. ${ }^{13}$ Because remarriage is only identifiable in the 1960-1980 censuses, I confine my attention to this period. Column three shows that this shorter sample yields similar results. Presumably this reflects the fact that only South Dakota adopted unilateral divorce laws after the 1970s. Further, this is consistent with the suggestion from Chart 3 that most of the rise in divorce occurred in the first eight years following legal reform.

Column four turns to analyzing the effect of divorce laws on the ever-divorced population. This broader measure reveals no effects of divorce laws on the ever-divorced population. Further, these results are about as precisely estimated as Gruber's. ${ }^{14}$

Thus census data suggest that no effect of divorce laws on the ever-divorced population is evident by 1980. By contrast, the flow data suggest that divorce rates rose over a corresponding period. Reconciling these findings hinges on the greater statistical precision of the flow estimates. The central estimates in Table 2 suggested that the divorce rate rose by about 0.2-0.3 divorces per thousand people per year, for

\footnotetext{
${ }^{10}$ For the sake of comparability, I revert to Gruber's coding of divorce laws when analyzing census data. Results using Friedberg's coding are similar.

${ }^{11}$ All of my data are from www.ipums.org. Following Gruber, I analyze data on US-born adults aged 25-50 from the $19601 \%$ sample, the 1970 Form one state $1 \%$ sample, and the 1980 and $19905 \%$ state samples. While divorce rates in each age-sex-state of residence-year cell are derived using person weights, regression weights reflect the number of observations used in constructing each cell, yielding estimates that are representative of the unbalanced microdata, rather than the US population.

${ }^{12}$ Correspondence with Gruber suggests that these minor differences may reflect different treatment of observations with certain missing or imputed values, and persons in group quarters.

${ }^{13}$ My measure of the ever-divorced population includes both those currently divorced and those who are married, separated or widowed, but are on their second (or higher) marriage. Implicitly this measure assumes that those who have remarried were divorced - rather than widowed - by their first spouse. June 1995 CPS data suggest that this is largely true: my proxy measure would categorize $26.9 \%$ of the female population aged $25-50$ as ever divorced. Of these, $12.9 \%$ are currently divorced, $13.5 \%$ have been divorced, but are currently married, widowed or separated, while only $0.3 \%$ are widows who remarried (and hence are misclassified as ever divorced).
} 
around a decade. To a first approximation, this suggests that the ever divorced population should have risen through the $1970 \mathrm{~s}$ by around 2-3 divorces per thousand people, or $0.2-0.3$ percent of the population in reform states. My estimates in Table 3 yield a 95\% confidence interval for this prediction ranging from -0.5 to +0.6 percent of the population. That is, the administrative divorce data suggest a very precisely estimated - but small - effect of unilateral divorce laws on divorce rates. The size of this effect is sufficiently small that it cannot be rejected in census data on the ever-divorced population. Both datasets suggest that unilateral divorce laws explain only a very small fraction of the dramatic rise in divorce over the past forty years.

\section{Interpretation}

Data on the flow of new divorces suggest that the shift to unilateral divorce had important—albeit relatively small — effects on the divorce rate over the decade following its adoption, a finding that the census data do not reject. Beyond that, the temporal pattern shown in Chart 3 presents a puzzle: why is the divorce rate lower when looking more than a decade after the adoption of unilateral divorce laws? In this section I explore four possible explanations: the dynamics associated with a shift toward earlier divorce rather than more divorce, changes in marriage rates, contamination of divorce norms from treatment states to control states and regression to the mean.

\section{Dynamics}

The increase in divorces for a decade following reform, and the subsequent decrease, may in fact be two sides of the same coin: unilateral divorce may have simply led to the earlier dissolution of bad matches, thereby shifting a number of divorces from the 1980s into the 1970s. Thus extending the data by a further decade may yield something closer to the true long run effects. For the divorce rate data, I extend the sample to 1998 using data reported in Vital Statistics. I cannot update data on the everdivorced population beyond 1980 because the Census stopped asking about remarriage. However I can update data on the share of the population currently divorced by pooling observations from the 1998-2000 CPS basic monthly data.

The first two columns of Table 4 show the results over this longer sample - panel A shows the effects on the flow data, and the negative coefficients remain a feature even a quarter of a century after the reform. The census data, shown in panel B, yield complementary results, although for brevity I only show results from the female sample. The stock of divorcees rose strongly in the decade following reform, remained at about the same level for the next decade, and reversed somewhat over the ensuing decade. While the results in Table 3 caution against the assumption that the evolution of the currently divorced population is representative of the number of divorces, these data are consistent with the finding that

\footnotetext{
${ }^{14}$ Reading the results in columns three and four together suggests that the share of the population who have divorced
} 
unilateral divorce laws only increased the flow of new divorces for about a decade. Once again estimates based on census data are sufficiently imprecise that they cannot falsify a wide range of dynamic responses.

\section{Matching}

The quality and quantity of marriage market matches may change in response to divorce law changes. Tempering this, even important changes to entry into marriage will only change the stock of existing marriages very slowly. Even so, one might expect that reduced exit costs would lead to lower quality matches, which might raise the divorce rate. Against this, the benefits of marriage (tying your spouse to a contract) are reduced in a no-fault world, and hence the proportion of the population that is married may decline. This suggests that divorces per thousand people is an inappropriate metric, and analysis should focus on divorces per thousand married people. Even so, there may be changes at the quality margin that this quantity adjustment does not address.

Columns three and four of Table 4 analyze divorces per thousand married people. ${ }^{15}$ Note that variable is scaled differently $-68 \%$ of the population is married, and hence the dependent variable has a mean of 5.9 rather than 3.9. These results yield an initial increase in divorce that is slightly more pronounced, while the subsequent decline is somewhat weaker than suggested by columns one and two.

\section{Contamination}

It seems likely that unilateral divorce laws affect the divorce rate both directly through changing legal parameters, and indirectly by reducing the stigma associated with divorce. A thicker remarriage market may further reduce the cost of divorce. Reduced divorce stigma and enhanced remarriage prospects are unlikely to respect state boundaries. Thus easier access to divorce in reform states may also reduce stigma in non-reform states, leading the divorce rate to rise, albeit with a lag. Further, it seems likely that legislative activism in reform states created pressure for more liberal judicial interpretation of ongoing consent divorce laws in other states (Rodgers et. al. 1999, Glenn 1999). Taking these factors together, it may be that my control states experienced de facto reform, leading the divorce rate to rise in the control states relative to that in the true reform states - possibly with a lag.

In the first column of Table 5 I attempt to control for the shock to local norms, by adding a control for the proportion of neighboring states with unilateral divorce laws. While a norms-based story suggests that this variable will have a positive coefficient, it turns out to be statistically significant and negative, a result that is suggestive of migratory divorce (the administrative flow data reflect the state in which the divorce is obtained). The estimated effect of a state reforming its own laws is largely unchanged. That said, this

and remarried declined in reform states. This is a rather curious feature of these results.

${ }^{15}$ That is, to create my new independent variable, I divide the divorce rate by the proportion of the adult population in a state that is currently married. This latter series is calculated by linearly interpolating decadal estimates derived from IPUMS microdata for 1950-1990 and pooled 1998-2000 CPS microdata. 
strategy does not control for contamination effects to the extent that they represent national rather than local phenomena. I now turn to examining this issue further.

\section{Regression to the Mean}

While the basic method of this literature has been quasi-experimental - arguing that variation in unilateral divorce laws is exogenous - a close reading of the reform movement suggests that this is only partly true. While the timing of these reforms (among reform states) was probably random (Jacob 1988), states with historically higher divorce rates were more likely to choose to reform their laws (Peters 1992). This suggests that convergence in divorce norms, or regression to the mean, may explain why divorce rates rose faster in control states, yielding negative coefficients.

Table 5 shows three attempts to highlight this issue. Columns three and four involve a simple control strategy, interacting a measure of the state's historical divorce propensity (the share of that state's population aged 25-50 that reported being ever divorced in the 1950 census), with a linear time trend, and time fixed effects, respectively. Column three confirms that the divorce rate spiked following reform, but highlights the fragility of the negative coefficients over the ensuing decade. Column four yields reasonably precise estimates suggesting no effect of unilateral divorce laws. Column five exploits only that variation that is clearly quasi-experimental, restricting the sample to reform states; thus the equation is identified only off the variation in timing of reform across reform states. In none of these cases do the long run effects of unilateral divorce laws appear to be significantly negative.

\section{Suggestive Insights from a Toy Model}

In sum, these results suggest that unilateral divorce laws had a discernible effect on divorce rates for about a decade. While this strictly falsifies the Coasian prediction, the more interesting question is whether the theory is "about right".

A very simple model provides some insight. A marriage yields a payoff to each spouse, $u_{h}$ to the husband, and $u_{w}$ to his wife. These payoffs are not known with certainty before marriage, and divorce arises when the realized payoff falls short of some reservation level of utility, $\hat{u}{ }^{16}$ To fix a very simple starting point, assume that $u_{h}$ and $u_{w}$ are independent random variables drawn from the $F(u)$, and that the reservation payoff, $\hat{u}$, is the same for all people.

In 1960, one-fifth of all women had been through a divorce by age 65 . Consider a strictly nonCoasian interpretation of this fact: in the absence of spousal bargaining, divorce only occurs in a consent regime if it is individually optimal for both partners. Hence the probability that divorce occurs is $p\left(u_{h}<\hat{u}\right.$ and $\left.u_{w}<\hat{u}\right)=F(\hat{u})^{2}$. Thus, $F(\hat{u})=\sqrt{ } 0.2 \approx 0.45$. That is, $45 \%$ of the population would prefer to get divorced.

\footnotetext{
${ }^{16}$ One interpretation is that this reservation utility level represents each person's outside option on the remarriage market. Alternatively, $\hat{u}$ represents the fixed wage contract proposed in Peters (1986).
} 
Thus, shifting to a regime in which divorce occurs upon the unilateral action of either spouse, the divorce rate is predicted to rise to: $1-(1-F(\hat{u}))^{2} \approx 70 \%$.

By contrast, the Coasian interpretation is that the $20 \%$ divorce rate under the consent divorce law reflects the efficient rate of marital dissolution, and under ideal bargaining conditions, the same number of divorces will occur under a unilateral divorce regime. In fact, the central results above are much closer to this latter prediction. A plausible estimate is that unilateral divorce laws led the probability of the dissolution of the first marriage to rise by one-quarter of a percentage point.

Further, these results can be used to make inferences about the costs of bargaining in marriage. Some structure must be imposed to yield stronger results, and I assume that the payoffs, $\left\{u_{h}, u_{w}\right\}$ are independent draws from a normal distribution (and by an innocuous normalization, this is the standard normal distribution). If there are no transaction costs involved in paying off your spouse to grant a divorce, then a consent regime yields the efficient number of divorces. Consequently divorce occurs if $u_{h}+u_{w}<2 \hat{u}$. Noting that $p\left(u_{w}+u_{h}<2 \hat{u}\right)=F_{N}(2 \hat{u} / \sqrt{ } 2)=20 \%$, where $F_{N}$ is the cumulative standard normal distribution, I can infer that $\hat{u} \approx 0.6$. Introduce a transaction cost, $C$, that applies if a spouse has to offer their partner a side payment to stay married under a unilateral divorce law. Thus, in addition to the efficient divorces, if $2 \hat{u}<u_{h}+u_{w}<2 \hat{u}+C$, divorce will also occur. ${ }^{17}$ That the rate of marital dissolution rose by a quarter of a percentage point implies:

$F_{N}((2 \hat{u}+C) / \sqrt{ } 2)-F_{N}(2 \hat{u} / \sqrt{ } 2)=.0025$, and hence $C=0.0063$.

A more directly interpretable scaling derives from considering a couple in which the husband is enjoying the average level of marital satisfaction $\left(u_{h}=0\right)$, and his wife is indifferent between staying married and divorcing $u_{w}=\hat{u}$. The total marital surplus accruing to this couple is $\hat{u}$, suggesting that bargaining to redistribute these rents (thereby saving the marriage), destroys one percent of this surplus $(C \approx 100 \hat{u})$. Another metric derives from considering the number of marriages saved by spousal bargaining. Assuming that the $20 \%$ divorce rate under the consent system reflected the share of marriages in which divorce was jointly optimal, this implies that a further $27 \%$ of the population were in marriages in which divorce was jointly sub-optimal, but preferred by at least one spouse (in the absence of side payments). The data indicate that the divorce rate rose by a quarter of a percentage point, suggesting that spousal bargaining to redistribute rents saved over $99 \%$ of these marriages. The transaction cost was larger than marital rents in the other $1 \%$ of these marriages.

An alternative interpretation turns on the correlation $(\rho)$ between $u_{h}$ and $u_{w}$. This correlation can be either positive - as where we enjoy bringing enjoyment to our spouses, or it can be negative - as where there are different sharing rules in different relationships. Under this interpretation, the measured effect of

\footnotetext{
${ }^{17}$ This is a simplifying approximation. Actually divorce will occur if $2 \hat{u}<u_{h}+u_{w}<2 \hat{u}+C$ and either $u_{h}<\hat{u}$ or $u_{w}<\hat{u}$.
} 
unilateral divorce laws can yield insight into the correlation of payoffs between spouses. If there is no marital bargaining, then the probability of a consent divorce is $F_{\rho}(\hat{u}, \hat{u})$, where $F_{\rho}\left(u_{h}, u_{w}\right)$ is the standard bivariate normal cdf when $\rho=\operatorname{corr}\left(u_{h}, u_{w}\right)$. Unilateral divorce occurs with probability $1-F_{\rho}(-\hat{u},-\hat{u})$. Matching these formulae to data yields two equations in two unknowns ( $\hat{u}$ and $\rho$ ). This alternative interpretation can explain the data in the absence of marital bargaining if $\rho$ exceeds 0.99 .

Of course, the truth probably lies somewhere between these two extreme assumptions of independent shocks, or no spousal bargaining. Nonetheless, it bears emphasizing that these findings are suggestive of either very small transaction costs, or a strongly positive correlation between the marital satisfaction of spouses. Further insight into this issue can be gained by examining changing distribution within marriage subsequent to the adoption of unilateral divorce laws. That said, without specifying a more complete theory of distribution in marriage, these back-of-the-envelope calculations should only be interpreted as suggestive.

\section{Conclusion}

A clear finding from this analysis is that the divorce rate exhibits interesting dynamics in response to a change in legal regime. As a result, standard difference-in-difference approaches are led to confound preexisting trends with the effects of the policy shock. A more plausible specification that takes explicit account of these dynamics yields new results that appear somewhat more robust.

The data broadly indicate that divorce law reform led to an immediate spike in the divorce rate that dissipates over time. After a decade, no effect can be discerned. This basic insight is robust to a range of alternative interpretations of divorce laws. Further, it is consistent with census data on the ever-divorced population. More puzzling, certain estimates suggest that the divorce rate declined over the ensuing period. This eventual decline in the divorce rate is less robust, and a range of alternative specifications suggests that this decline may be illusory.

These results do not yield a particularly clear answer to the motivating theoretical question of whether Coasian bargaining occurs between spouses. It is clear that divorce law has an effect on the divorce rate; it is less clear that this effect is persistent. The estimated magnitudes suggest either that there is substantial agreement between spouses as to whether or not to seek a divorce, or that transaction costs are relatively small, facilitating considerable bargaining over rents.

I find less equivocal results regarding the motivating policy question: what caused the dramatic rise in US divorces through the 1970s? Chart 6 maps the aggregate divorce rate against a counterfactual in which no states adopted unilateral divorce laws. It should be clear that unilateral divorce laws explain very little of the rise in the aggregate divorce rate. 


\section{References}

Allen, Douglas A. (1992) “Marriage and Divorce: Comment” American Economic Review, 82(3).

Becker, Gary (1981) A Treatise on the Family, Harvard University Press: Cambridge.

Binner, J.M. and A.W. Dnes (2001) "Marriage, Divorce and Legal Change: New Evidence From England and Wales", Economic Inquiry 39(2).

Brinig, Margaret F. (1998) "No-Fault Laws and At-Fault People", International Review of Law and Economics 18.

Dewald, William G., Jerry G. Thursby, and Richard G. Anderson (1986) "Replication in Empirical Economics: The Journal of Money, Credit and Banking Project", American Economic Review, 76(4).

Ellman, Ira M. and Sharon L. Lohr (1998) "Dissolving the Relationship Between Divorce Laws and Divorce Rates", International Review of Law and Economics 18.

Ellman, Ira (2000) "Divorce Rates, Marriage Rates, and the Problematic Persistence of Marital Roles", Family Law Quarterly, 34(1).

Friedberg, Leora (1998) "Did Unilateral Divorce Raise Divorce Rates? Evidence from Panel Data", American Economic Review, 88(3).

Gatland, Laura (1997) "Putting the Blame on No-Fault", American Bar Association Journal, v.83.

Glenn, Norval D. (1997) “A Reconsideration of the Effect of No-Fault Divorce on Divorce Rates", Journal of Marriage and the Family, 59(4).

Glenn, Norval D. (1999) "Further Discussion of the Effects of No-Fault Divorce on Divorce Rates", Journal of Marriage and the Family, 61(3).

Gruber, Jonathan (2000) "Is Making Divorce Easier Bad for Children? The Long Run Implications of Unilateral Divorce”, NBER Working Paper 7968.

Jacob, Herbert (1988) Silent Revolution: The Transformation of Divorce Law in the United States. University of Chicago Press: Chicago.

Johnson, John H. and Christopher J. Mazingo (2000) "The Economic Consequences of Unilateral Divorce for Children", University of Illinois CBA Office of Research Working Paper 00-011.

McCullough, B.D. and H.D. Vinod (1999) "The Numerical Reliability of Econometric Software" Journal of Economic Literature Vol.XXXVII, June 1999, p.633-665.

Mechoulan, Stephane (2001) "Divorce Laws and the Structure of the American Family", mimeo Northwestern University.

Nakonezny, P.A., Shull, R.D. and Rodgers, J.L. (1995) "The Effect of No-Fault Divorce Law on the Divorce Rate Across the 50 States and its Relation to Income, Education and Religiosity", Journal of Marriage and the Family, 57(2).

Peters, H. Elizabeth (1986) "Marriage and Divorce: Informational Constraints and Private Contracting" American Economic Review 76(3).

Peters, H. Elizabeth (1992) "Marriage and Divorce: Reply" American Economic Review, 82(3). 
Rodgers, J.L. P.A. Nakonezny and R.D. Shull (1997) "The Effect of No-Fault Divorce Legislation: A Response to a Reconsideration" Journal of Marriage and the Family, 59(4).

Rodgers, J.L. P.A. Nakonezny and R.D. Shull (1999) "Did No-Fault Divorce Legislation Matter? Definitely Yes and Sometimes No" Journal of Marriage and the Family, 61(3).

Rowthorn, Robert (1999) "Marriage and Trust: Some Lessons from Economics" Cambridge Journal of Economics, 23(5).

Stevenson, Betsey and Justin Wolfers (2003) “"Til Death Do Us Part: The Effects of Divorce Law on Suicide, Domestic Violence and Intimate Homicide", mimeo Stanford GSB. 
Table 1: Friedberg's Results

Dependent Variable: Annual divorces per thousand people

\begin{tabular}{|c|c|c|c|}
\hline & $\begin{array}{c}\text { (1) } \\
\text { Basic Specification }\end{array}$ & $\begin{array}{c}(2) \\
\text { State-Specific } \\
\text { Trends } \\
\text { Linear }\end{array}$ & $\begin{array}{c}\text { (3) } \\
\text { State-Specific } \\
\text { Trends } \\
\text { Quadratic }\end{array}$ \\
\hline \multicolumn{4}{|c|}{ Panel A: Friedberg (1998) } \\
\hline Unilateral & $\begin{array}{c}0.004 \\
(0.056)\end{array}$ & $\begin{array}{l}0.447^{* * * *} \\
(0.050)\end{array}$ & $\begin{array}{l}0.441^{* * * *} \\
(0.055)\end{array}$ \\
\hline $\begin{array}{l}\text { Year Effects } \\
\text { State Effects } \\
\text { State Trend, Linear } \\
\text { State Trend, Quadratic } \\
\text { Adjusted } \mathrm{R}^{2}\end{array}$ & $\begin{array}{c}\text { Yes, } \mathrm{F}=89.0^{* * *} \\
\text { Yes, } \mathrm{F}=217.3^{* * *} \\
\text { No } \\
\text { No } \\
0.946\end{array}$ & $\begin{array}{c}\text { Yes, } \mathrm{F}=95.3^{* * *} \\
\text { Yes, } \mathrm{F}=196.2^{* * *} \\
\text { Yes, } \mathrm{F}=24.7^{* * *} \\
\text { No } \\
0.976\end{array}$ & $\begin{array}{c}\text { Yes, } \mathrm{F}=8.9^{* * *} \\
\text { Yes, } \mathrm{F}=131.1^{* * *} \\
\text { Yes, } \mathrm{F}=9.3^{* * *} \\
\text { Yes, } \mathrm{F}=6.5^{* * *} \\
0.982\end{array}$ \\
\hline \multicolumn{4}{|c|}{ Panel B: Replication } \\
\hline Unilateral & $\begin{array}{c}0.000 \\
(0.057)\end{array}$ & $\begin{array}{l}0.431^{* * * *} \\
(0.051)\end{array}$ & $\begin{array}{l}0.435^{* * *} \\
(0.055)\end{array}$ \\
\hline $\begin{array}{l}\text { Year Effects } \\
\text { State Effects } \\
\text { State Trend, Linear } \\
\text { State Trend, Quadratic } \\
\text { Adjusted } \mathrm{R}^{2}\end{array}$ & $\begin{array}{c}\text { Yes, } \mathrm{F}=89.3^{* * *} \\
\text { Yes, } \mathrm{F}=216.5^{* * *} \\
\text { No } \\
\text { No } \\
0.946\end{array}$ & $\begin{array}{c}\text { Yes, } \mathrm{F}=95.3^{* * *} \\
\text { Yes, } \mathrm{F}=191.6^{* * *} \\
\text { Yes, } \mathrm{F}=24.4^{* * *} \\
\text { No } \\
0.976\end{array}$ & $\begin{array}{c}\text { Yes, } \mathrm{F}=9.0^{* * *} \\
\text { Yes, } \mathrm{F}=129.1^{* * *} \\
\text { Yes, } \mathrm{F}=9.3^{* * *} \\
\text { Yes, } \mathrm{F}=6.6^{* * *} \\
0.981\end{array}$ \\
\hline
\end{tabular}

Sample: 1968-1988, $\mathrm{n}=1043$ (unbalanced panel).

Estimated using state population weights.

${ }^{* * *},{ }^{* *}$ and ${ }^{*}$ respectively denote significant at $1 \%, 5 \%$ and $10 \%$ levels. (Standard errors in parentheses)

Sources: Divorce rate data coded by Friedberg (1998) from Vital Statistics. Divorce laws coded from

Friedberg's Table 1. Population weights downloaded from www.census.gov. 
Table 2: Dynamic Effects of Adopting Unilateral Divorce Laws

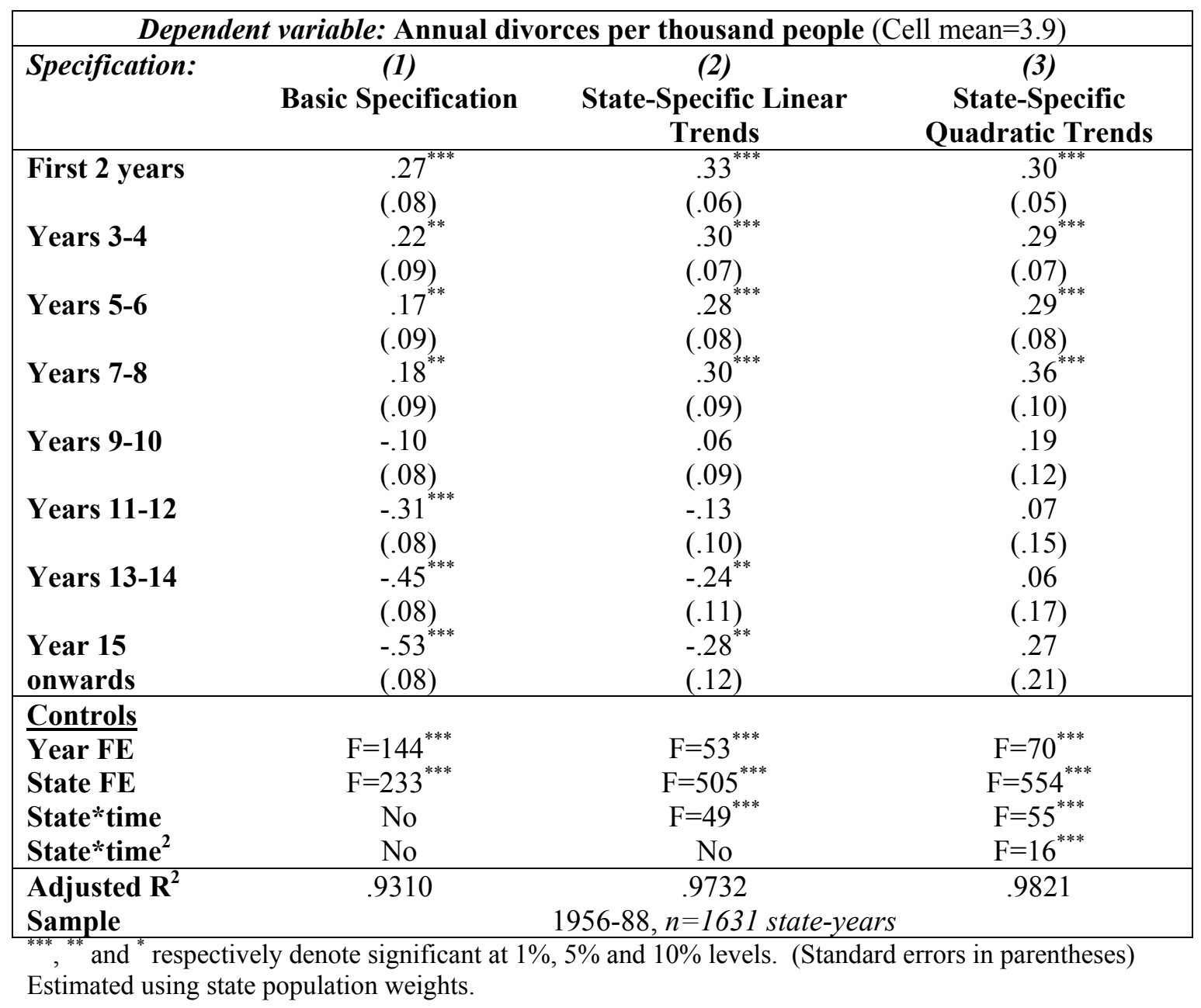


Table 3: Effects of Unilateral Divorce Laws on the Stock of Divorces - Census Data

\begin{tabular}{|c|c|c|c|c|}
\hline \multirow{2}{*}{$\begin{array}{l}\text { Dependent } \\
\text { Variable }\end{array}$} & \multicolumn{3}{|c|}{ p(Currently Divorced) } & \multirow{2}{*}{$\begin{array}{c}\text { p(Ever Divorced) } \\
\text { Dependent } \\
\text { variable is } \\
\text { "ever divorced" } \\
\text { (shorter sample) }\end{array}$} \\
\hline & $\begin{array}{c}\text { Gruber's } \\
\text { Results }\end{array}$ & $\begin{array}{c}\text { Replicating } \\
\text { Gruber } \\
\text { (same sample) }\end{array}$ & $\begin{array}{c}\text { Replicating } \\
\text { Gruber } \\
\text { (shorter sample) }\end{array}$ & \\
\hline \multicolumn{5}{|c|}{ Panel A: Women } \\
\hline $\begin{array}{l}\text { Mean of } \\
\text { Dependent Var }\end{array}$ & $11.0 \%$ & $11.2 \%$ & $9.2 \%$ & $22.5 \%$ \\
\hline $\begin{array}{l}\text { Unilateral } \\
\text { Coefficient }\end{array}$ & $\begin{array}{l}.0128^{* * *} \\
(.0026)\end{array}$ & $\begin{array}{l}.0102^{* * *} \\
(.0021)\end{array}$ & $\begin{array}{l}.0104^{* * *} \\
(.0018)\end{array}$ & $\begin{array}{c}.0009 \\
(.0025)\end{array}$ \\
\hline Elasticity & $11.6 \%$ & $9.1 \%$ & $11.3 \%$ & $0.4 \%$ \\
\hline \multicolumn{5}{|c|}{ Panel B: Men } \\
\hline $\begin{array}{l}\text { Mean of } \\
\text { Dependent Var }\end{array}$ & $8.2 \%$ & $8.5 \%$ & $6.8 \%$ & $19.3 \%$ \\
\hline $\begin{array}{l}\text { Unilateral } \\
\text { Coefficient }\end{array}$ & $\begin{array}{l}.0095^{* * *} \\
(.0026)\end{array}$ & $\begin{array}{l}.0081^{* * *} \\
(.0023)\end{array}$ & $\begin{array}{l}.0082^{* * *} \\
(.0017)\end{array}$ & $\begin{array}{l}.0004 \\
(.0027)\end{array}$ \\
\hline Elasticity & $11.6 \%$ & $9.5 \%$ & $12.1 \%$ & $0.2 \%$ \\
\hline Sample & $\begin{array}{l}1960-90 \\
n=5304\end{array}$ & $\begin{array}{l}1960-90 \\
n=5304\end{array}$ & $\begin{array}{l}1960-80 \\
n=3978\end{array}$ & $\begin{array}{l}1960-80 \\
n=3978\end{array}$ \\
\hline
\end{tabular}

${ }^{* * *},{ }^{* *}$ and ${ }^{*}$ respectively denote significant at $1 \%, 5 \%$ and $10 \%$ levels. (Standard errors in parentheses) Weighted to reflect underlying microdata. Standard errors clustered at state*year level.

All regressions based on IPUMS data from the 1950-90 Censuses: 1960 1\% state sample, 1970 Form one 1\% state sample, 1980 and 1990 5\% state samples. Restricted to US-born population aged 25-50.

Each coefficient is from a separate regression, controlling for race, state of residence dummies, age dummies, year dummies, and age*year dummy interactions. 
Table 4: Long-Run Effects of Unilateral Divorce Laws

\begin{tabular}{|c|c|c|c|c|}
\hline \multirow[t]{2}{*}{$\begin{array}{l}\text { Dependent } \\
\text { variable }\end{array}$} & \multicolumn{2}{|c|}{$\begin{array}{c}\text { Divorce Rate } \\
\text { (per thousand people per year) }\end{array}$} & \multicolumn{2}{|c|}{$\begin{array}{l}\text { Divorces per thousand married } \\
\text { people aged } 18 \text { plus }\end{array}$} \\
\hline & $\begin{array}{c}\text { 1956-88 Sample } \\
n=1631\end{array}$ & $\begin{array}{l}\mathbf{1 9 5 6 - 9 8} \\
\text { Sample } \\
n=2102\end{array}$ & $\begin{array}{c}\text { 1956-88 Sample } \\
n=1631\end{array}$ & $\begin{array}{c}\text { 1956-98 Sample } \\
n=2102\end{array}$ \\
\hline \multicolumn{5}{|c|}{ Panel A: Dependent Variable is Divorce Rate (Administrative flow data) } \\
\hline Cell Mean & 3.9 & 4.1 & 5.9 & 6.2 \\
\hline \multicolumn{5}{|c|}{ Law Change has been in effect for: } \\
\hline \multirow[t]{2}{*}{ First 2 years } & $.27^{* * *}$ & $.28^{* * *}$ & $.43^{* * *}$ & $.43^{* * *}$ \\
\hline & $(.08)$ & $(.10)$ & $(.12)$ & $(.13)$ \\
\hline \multirow[t]{2}{*}{ Years 3-4 } & $.22^{* *}$ & $.23^{* *}$ & $.38^{* * * *}$ & $.39^{* * *}$ \\
\hline & $(.09)$ & $(.10)$ & $(.12)$ & $(.13)$ \\
\hline \multirow[t]{2}{*}{ Years 5-6 } & $.17^{* *}$ & $.19^{* *}$ & $.36^{* * *}$ & $.37^{* * *}$ \\
\hline & $(.09)$ & $(.10)$ & $(.12)$ & $(.13)$ \\
\hline \multirow[t]{2}{*}{ Years 7-8 } & $.18^{* *}$ & $.20^{* *}$ & $.41^{* * *}$ & $.43^{* * *}$ \\
\hline & $(.09)$ & $(.10)$ & $(.12)$ & $(.13)$ \\
\hline \multirow[t]{2}{*}{ Years 9-10 } & -.10 & -.06 & .04 & .07 \\
\hline & $(.08)$ & $(.10)$ & $(.11)$ & $(.13)$ \\
\hline \multirow[t]{2}{*}{ Years 11-12 } & $-.31^{* * * *}$ & $-.27^{* * *}$ & $-.24^{* *}$ & -.20 \\
\hline & $(.08)$ & $(.09)$ & $(.11)$ & $(.13)$ \\
\hline \multirow[t]{2}{*}{ Years 13-14 } & $-.45^{* * *}$ & $-.39^{* * *}$ & $-.44^{* * *}$ & $-.38^{* * * *}$ \\
\hline & $(.08)$ & $(.09)$ & $(.11)$ & $(.13)$ \\
\hline Years 15-16 & $-.53^{* * *}$ & $-.38^{* * *}$ & $-.48^{* * *}$ & $-.33^{* * *}$ \\
\hline$($ Year $15+\operatorname{cols} 1,3)$ & $(.08)$ & $(.09)$ & $(.11)$ & $(.13)$ \\
\hline \multirow[t]{2}{*}{ Years 17-18 } & & $-.47^{* * *}$ & & $-.44^{* * *}$ \\
\hline & & $(.09)$ & & $(.13)$ \\
\hline \multirow[t]{2}{*}{ Years 19-20 } & & $-.61^{* * *}$ & & $-.65^{* * *}$ \\
\hline & & $(.09)$ & & $(.13)$ \\
\hline \multirow[t]{2}{*}{ Years 21-22 } & & $-.70^{* * *}$ & & $-.81^{* * *}$ \\
\hline & & $(.10)$ & & $(.13)$ \\
\hline \multirow[t]{2}{*}{ Years 23-24 } & & $-.62^{* * *}$ & & $-.68^{* * *}$ \\
\hline & & $(.10)$ & & $(.14)$ \\
\hline \multirow[t]{2}{*}{ Year 25 plus } & & $-.73^{* * *}$ & & $-.86^{* * *}$ \\
\hline & & $(.10)$ & & $(.14)$ \\
\hline \multicolumn{5}{|c|}{$\begin{array}{c}\text { Panel B: Dependent Variable is Share of Population Currently Divorced (Census Data) } \\
\text { Female Sample }\end{array}$} \\
\hline \multirow{2}{*}{$\begin{array}{l}\text { Dependent } \\
\text { variable }\end{array}$} & \multicolumn{2}{|c|}{ p(Currently divorced) } & \multicolumn{2}{|c|}{ p(Currently divorced $\mid$ Ever married $)$} \\
\hline & $\begin{array}{c}\text { 1960-90 Sample } \\
n=5304\end{array}$ & $\begin{array}{l}\text { 1960-00 } \\
\text { Sample } \\
n=6630\end{array}$ & $\begin{array}{c}\text { 1960-90 Sample } \\
n=5304\end{array}$ & $\begin{array}{c}\text { 1960-00 Sample } \\
n=6630\end{array}$ \\
\hline Cell Mean & $9.9 \%$ & $10.2 \%$ & $12.8 \%$ & $13.2 \%$ \\
\hline \multicolumn{5}{|c|}{ Law Change has been in effect for: } \\
\hline 1 to 10 years & $\begin{array}{l}.01017^{* * *} \\
(.00254)\end{array}$ & $\begin{array}{l}.01077^{* * *} \\
(.00314)\end{array}$ & $\begin{array}{l}.01049^{* * *} \\
(.00270)\end{array}$ & $.01135^{* * *}$ \\
\hline 11 to 20 years & $.01027^{* * *}$ & $.01021^{* * *}$ & $.01104^{* * *}$ & $.01110^{* * *}$ \\
\hline $\begin{array}{l}(11 \text { years }+ \text { cols } \\
1,3)\end{array}$ & $(.00244)$ & $(.00218)$ & $(.00251)$ & $(.00229)$ \\
\hline 20 years plus & & $\begin{array}{c}.00341 \\
(.00369)\end{array}$ & & $\begin{array}{c}.00342 \\
(.00418)\end{array}$ \\
\hline
\end{tabular}

Panel A: See notes to Table 2. Panel B: See notes to Table 3. 
Table 5: Robustness Testing

Dependent Variable: Annual divorces per thousand people

\begin{tabular}{|c|c|c|c|c|c|}
\hline & $\begin{array}{c}\text { From } \\
\text { Table } 4 \\
\text { (column 2) } \\
\text { (1) }\end{array}$ & $\begin{array}{l}\text { Control for } \\
\text { Neighbor's } \\
\text { reforms } \\
\text { (2) }\end{array}$ & $\begin{array}{l}\text { Control for } \\
\text { historical } \\
\text { divorce rate } \\
\text { * Time } \\
\text { Trend } \\
\text { (3) } \\
\end{array}$ & $\begin{array}{l}\text { Control for } \\
\text { historical } \\
\text { divorce rate } \\
\text { * Time FE } \\
\text { (4) }\end{array}$ & $\begin{array}{c}\text { Reform } \\
\text { states only } \\
\text { (5) }\end{array}$ \\
\hline \multicolumn{6}{|c|}{ Law Change has been in effect for: } \\
\hline First 2 years & $\begin{array}{l}.28^{* * *} \\
(.10)\end{array}$ & $\begin{array}{l}.27^{* * *} \\
(.10)\end{array}$ & $\begin{array}{l}.37^{* * *} \\
(.09)\end{array}$ & $\begin{array}{l}.15 \\
(.09)\end{array}$ & $\begin{array}{l}.46^{* * *} \\
(.15)\end{array}$ \\
\hline Years 3-4 & $\begin{array}{l}.23^{* *} \\
(.10)\end{array}$ & $\begin{array}{l}.26^{* * *} \\
(.10)\end{array}$ & $\begin{array}{l}.36^{* * *} \\
(.09)\end{array}$ & $\begin{array}{l}.12 \\
(.10)\end{array}$ & $\begin{array}{l}.57^{* * *} \\
(.19)\end{array}$ \\
\hline Years 5-6 & $\begin{array}{l}.19^{* *} \\
(.10)\end{array}$ & $\begin{array}{l}.24^{* *} \\
(.10)\end{array}$ & $\begin{array}{l}.36^{* * *} \\
(.09)\end{array}$ & $\begin{array}{l}.11 \\
(.10)\end{array}$ & $\begin{array}{l}.66^{* * *} \\
(.22)\end{array}$ \\
\hline Years 7-8 & $\begin{array}{l}.20^{* *} \\
(.10)\end{array}$ & $\begin{array}{l}.24^{* *} \\
(.10)\end{array}$ & $\begin{array}{l}.40^{* * *} \\
(.09)\end{array}$ & $\begin{array}{l}.17 \\
(.09)\end{array}$ & $\begin{array}{l}.75^{* * *} \\
(.26)\end{array}$ \\
\hline Years 9-10 & $\begin{array}{l}-.06 \\
(.10)\end{array}$ & $\begin{array}{l}-.03 \\
(.10)\end{array}$ & $\begin{array}{l}.18^{* *} \\
(.09)\end{array}$ & $\begin{array}{l}-.01 \\
(.09)\end{array}$ & $\begin{array}{l}.54^{*} \\
(.29)\end{array}$ \\
\hline Years 11-12 & $\begin{array}{l}-.27^{* * *} \\
(.09)\end{array}$ & $\begin{array}{l}-.23^{* *} \\
(.09)\end{array}$ & $\begin{array}{l}.01 \\
(.09)\end{array}$ & $\begin{array}{l}-.16 \\
(.09)\end{array}$ & $\begin{array}{l}.34 \\
(.32)\end{array}$ \\
\hline Years 13-14 & $\begin{array}{l}-.39^{* * *} \\
(.09)\end{array}$ & $\begin{array}{l}-.36^{* * *} \\
(.09)\end{array}$ & $\begin{array}{l}-.07 \\
(.09)\end{array}$ & $\begin{array}{l}-.18 \\
(.09)\end{array}$ & $\begin{array}{l}.20 \\
(.35)\end{array}$ \\
\hline Years 15-16 & $\begin{array}{l}-.38^{* * *} \\
(.09)\end{array}$ & $\begin{array}{l}-.35^{* * *} \\
(.09)\end{array}$ & $\begin{array}{l}-.02 \\
(.09)\end{array}$ & $\begin{array}{l}-.10 \\
(.09)\end{array}$ & $\begin{array}{l}.17 \\
(.39)\end{array}$ \\
\hline Years 17-18 & $\begin{array}{l}-.47^{* * *} \\
(.09)\end{array}$ & $\begin{array}{l}-.43^{* * *} \\
(.09)\end{array}$ & $\begin{array}{l}-.05 \\
(.09)\end{array}$ & $\begin{array}{l}-.08 \\
(.09)\end{array}$ & $\begin{array}{l}.02 \\
(.42)\end{array}$ \\
\hline Years 19-20 & $\begin{array}{l}-.61^{* * *} \\
(.09)\end{array}$ & $\begin{array}{l}-.57^{* * *} \\
(.09)\end{array}$ & $\begin{array}{l}-.13 \\
(.09)\end{array}$ & $\begin{array}{l}-.14 \\
(.10)\end{array}$ & $\begin{array}{l}-.19 \\
(.45)\end{array}$ \\
\hline Years 21-22 & $\begin{array}{l}-.70^{* * *} \\
(.10)\end{array}$ & $\begin{array}{l}-.67^{* * *} \\
(.10)^{* * *}\end{array}$ & $\begin{array}{l}-.22^{* *} \\
(.10)\end{array}$ & $\begin{array}{l}-.24 \\
(.10)\end{array}$ & $\begin{array}{l}-.35 \\
(.48)\end{array}$ \\
\hline Years 23-24 & $\begin{array}{l}-.62^{* * *} \\
(.10)\end{array}$ & $\begin{array}{l}-.59^{* * *} \\
(.10)\end{array}$ & $\begin{array}{l}-.16 \\
(.10)\end{array}$ & $\begin{array}{l}-.11 \\
(.10)\end{array}$ & $\begin{array}{l}-.25 \\
(.52)\end{array}$ \\
\hline Year 25 plus & $\begin{array}{l}-.73^{* * *} \\
(.10)\end{array}$ & $\begin{array}{l}-.70^{* * *} \\
(.10)\end{array}$ & $\begin{array}{l}-.20 \\
(.10)\end{array}$ & $\begin{array}{l}-.04 \\
(.10)\end{array}$ & $\begin{array}{l}-.26 \\
(.56)\end{array}$ \\
\hline \multicolumn{2}{|c|}{ \% Unilateral (adjoining states) } & $\begin{array}{l}-.28^{* * *} \\
(.09)\end{array}$ & & & \\
\hline \multicolumn{2}{|c|}{ Time*historical divorce rate ${ }^{a}$} & & $\begin{array}{l}-.72^{* * *} \\
(.05)\end{array}$ & & \\
\hline \multicolumn{3}{|c|}{ Time FE * historical divorce rate } & & Yes & \\
\hline Sample & $\begin{array}{l}1956-98 \\
n=2102\end{array}$ & $\begin{array}{l}1956-98 \\
n=2102\end{array}$ & $\begin{array}{l}1956-98 \\
n=2102\end{array}$ & $\begin{array}{l}1956-98 \\
n=2102\end{array}$ & $\begin{array}{c}1956-98 \\
n=1202 \\
(29 \text { states })\end{array}$ \\
\hline
\end{tabular}




\section{Chart 1}

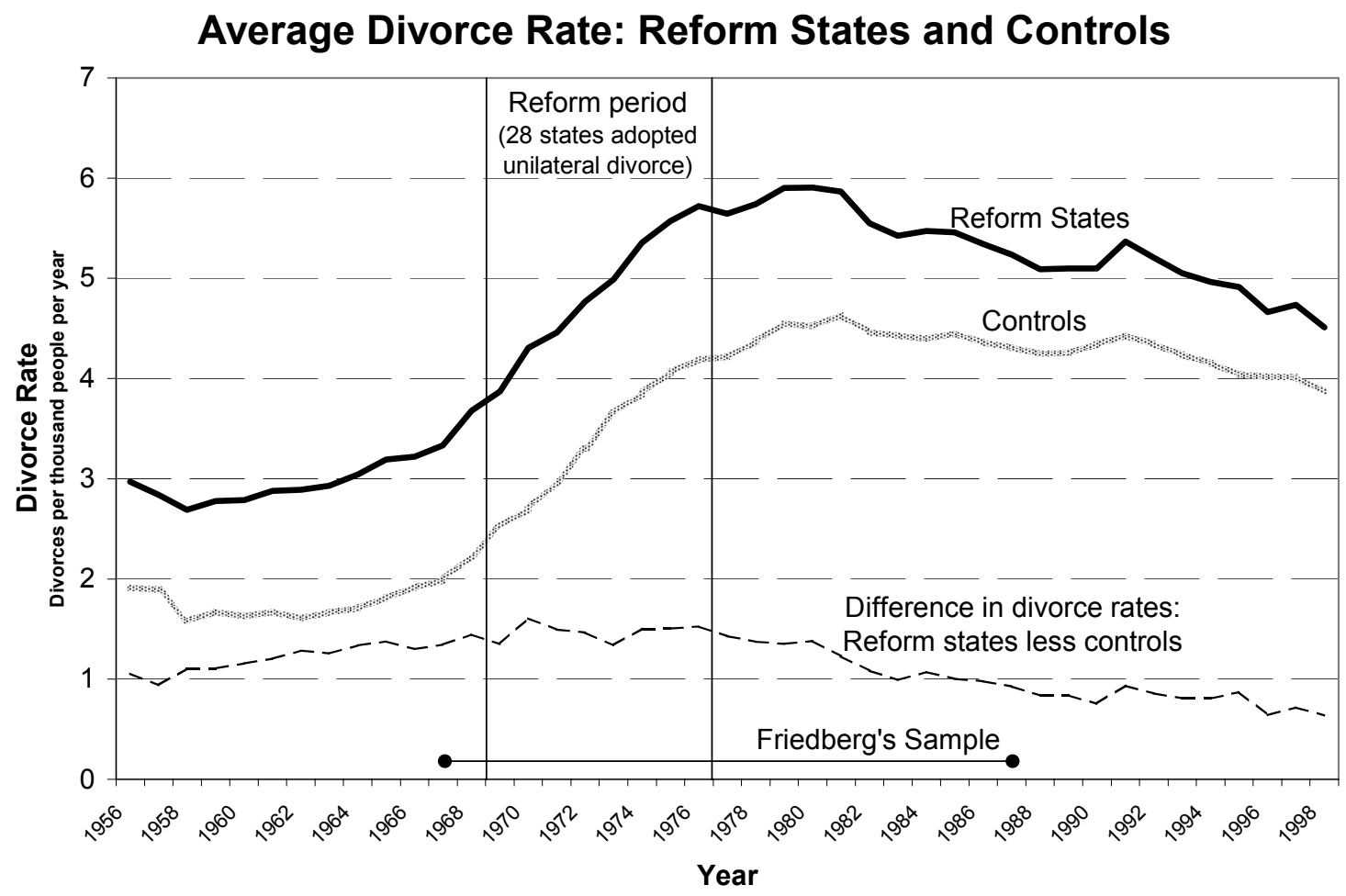

Chart 2

Dynamic Response of the Divorce Rate

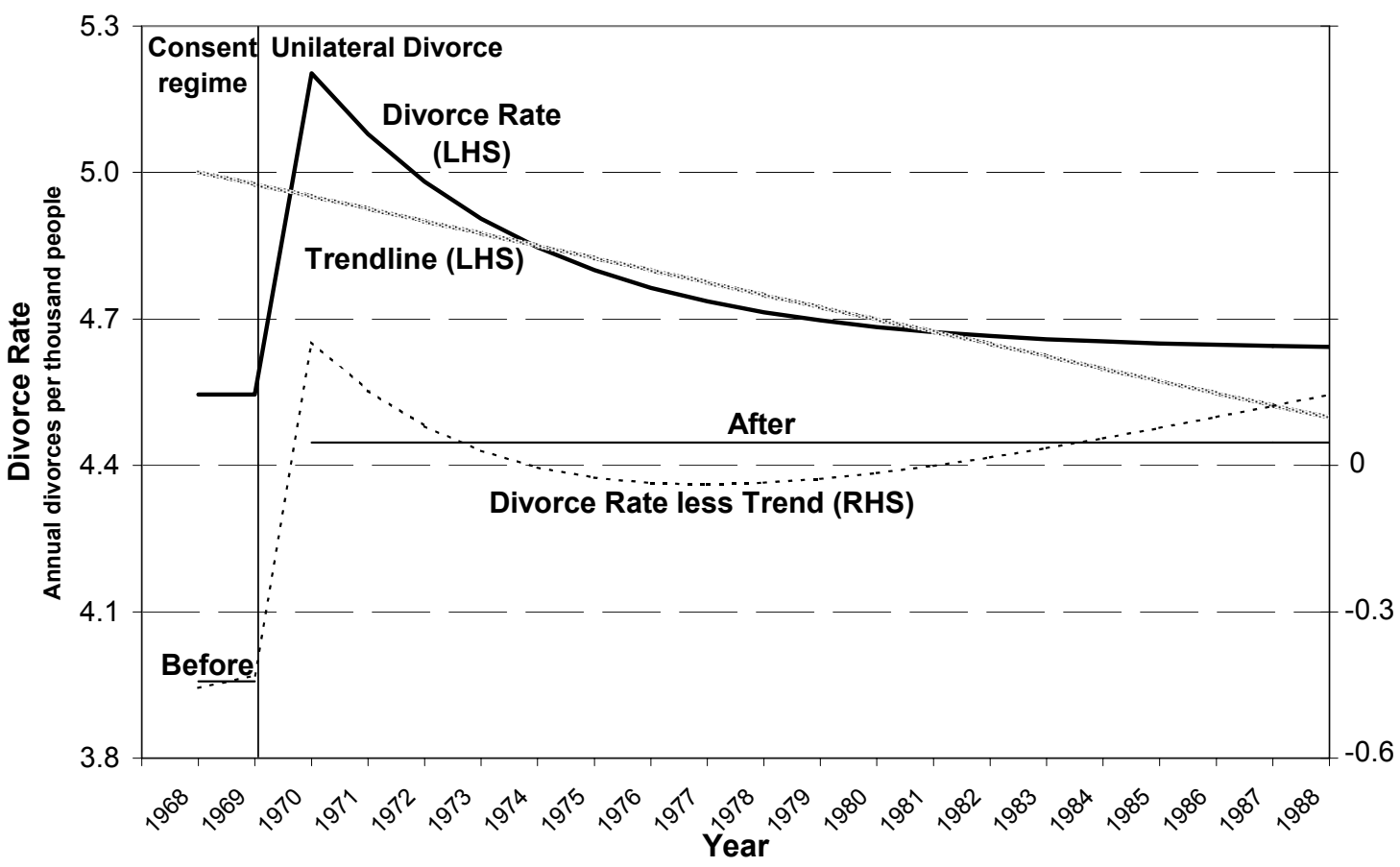

Notes: This hypothetical response of the divorce rate is constructed under the following assumptions: each year $20 \%$ of the population assess whether to get divorced, given the current legal regime. Under consent divorce, the $20 \%$ most incompatible matches dissolve; under unilateral divorce, this rises to $20.4 \%$. Each year $2.5 \%$ of the ever-divorced population die, and are replaced by newborns. 


\section{Chart 3}

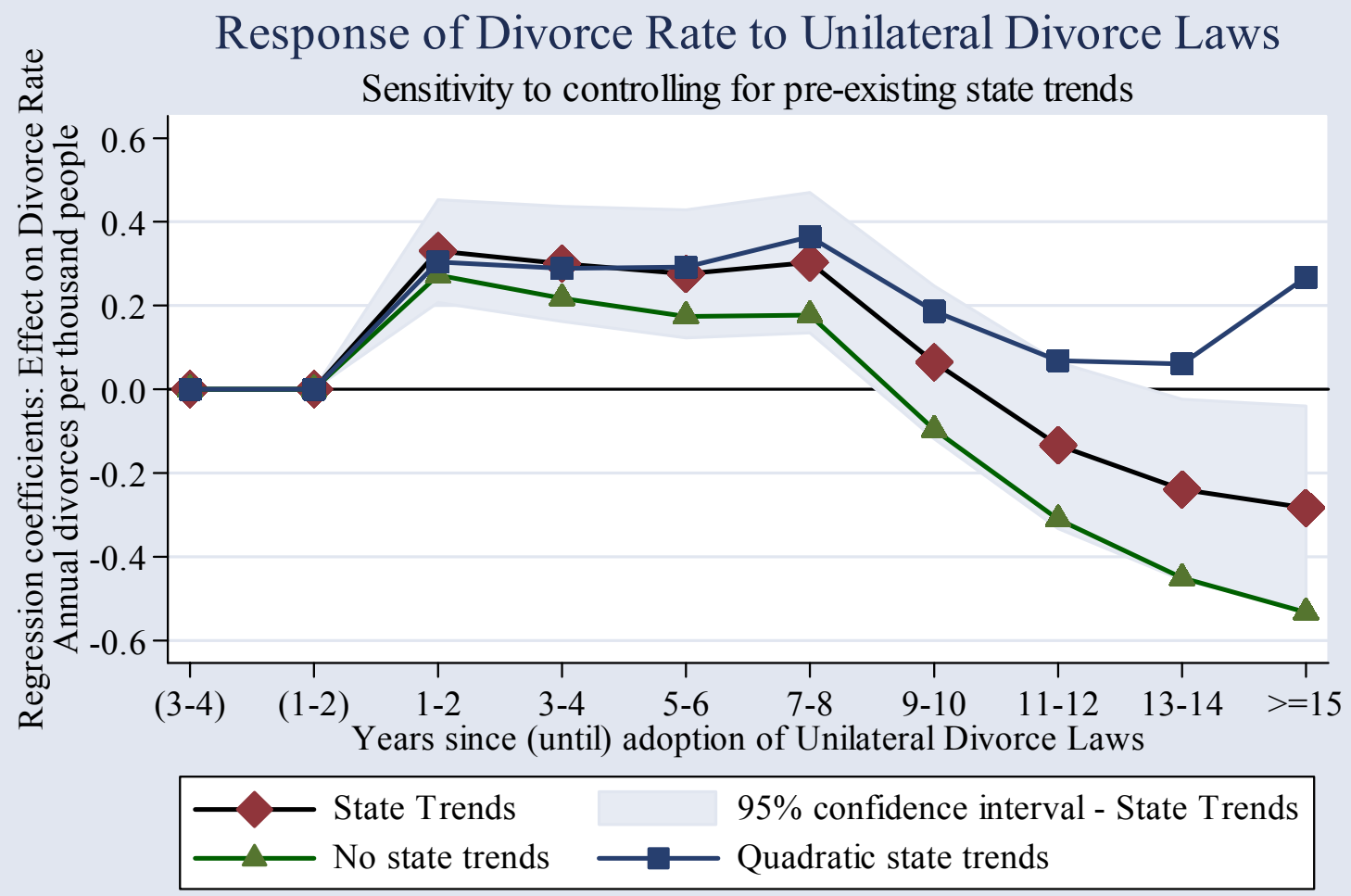

All regressions control for state and year fixed effects. For details, see table 2. 


\section{Chart 4}

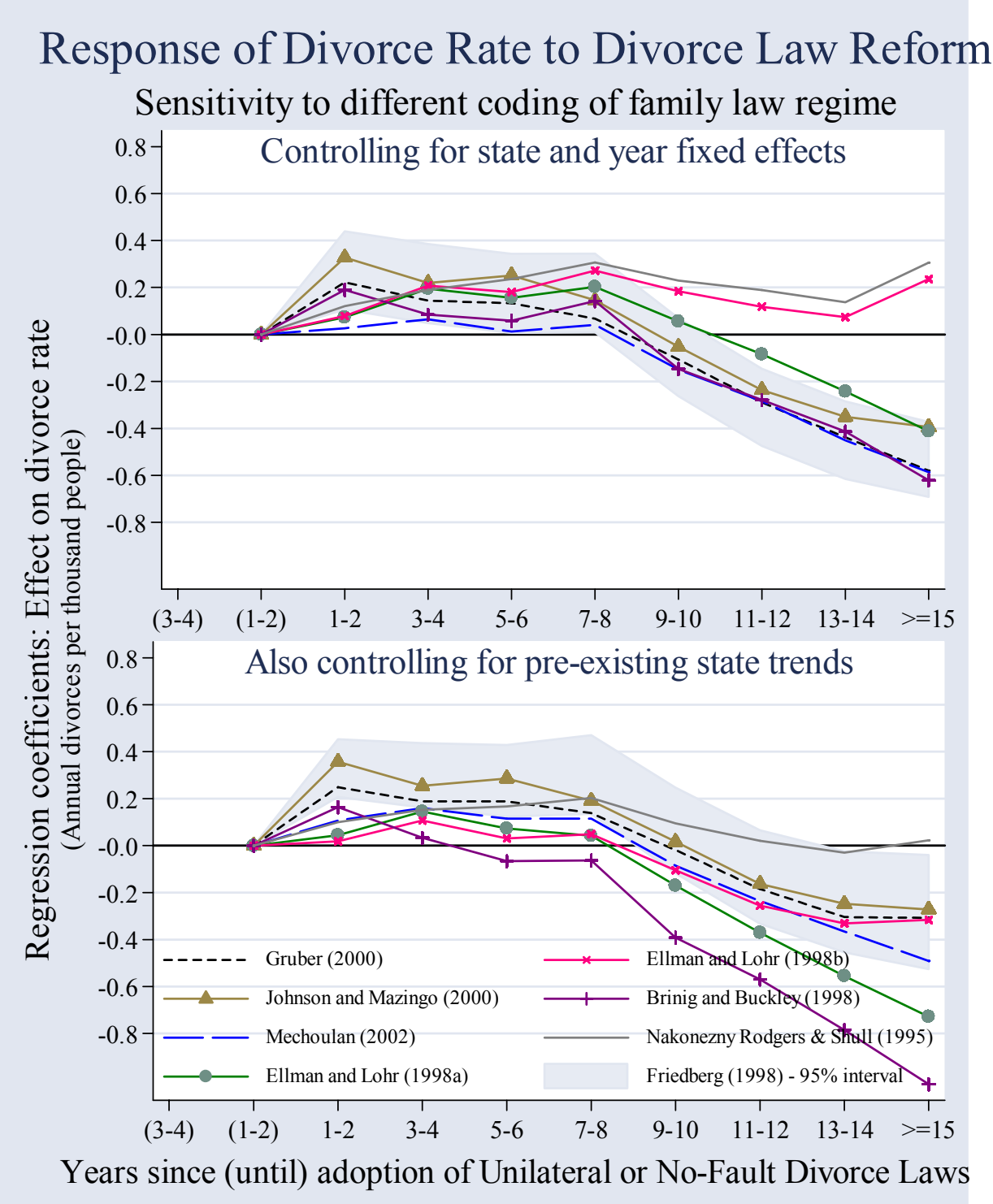

Notes: Chart shows regression coefficients from a specification including state and year fixed effects (and also state-specific linear time trends in bottom panel), estimated over the 1956-88 sample.

a) Friedberg (1998) codes when unilateral divorce laws, with no separation requirements are adopted, using mostly secondary sources.

b) Gruber (2000) codes unilateral divorce laws, with no separation requirements, using both primary and secondary sources.

c) Johnson and Mazingo (2000) code unilateral divorce laws, citing Friedberg and Brinig as sources.

d) Ellman and Lohr (1998a) code when each state adopted "irretrievable breakdown" as grounds for divorce, citing both primary and secondary sources.

e) Ellman and Lohr (1998b) code when each state adopted either "irretrievable breakdown" or "incompatibility / separation" as grounds for divorce.

f) Brinig and Buckley (1998) code is the date by which both no-fault grounds for dissolution and no-fault grounds for financial settlements have been adopted, citing both legislation and court decisions.

g) Nakonezny, Shull and Rodgers (1995) code the date of the state's adoption of no-fault grounds for either marital dissolution or financial settlements, citing mainly secondary sources. 


\section{Chart 5}

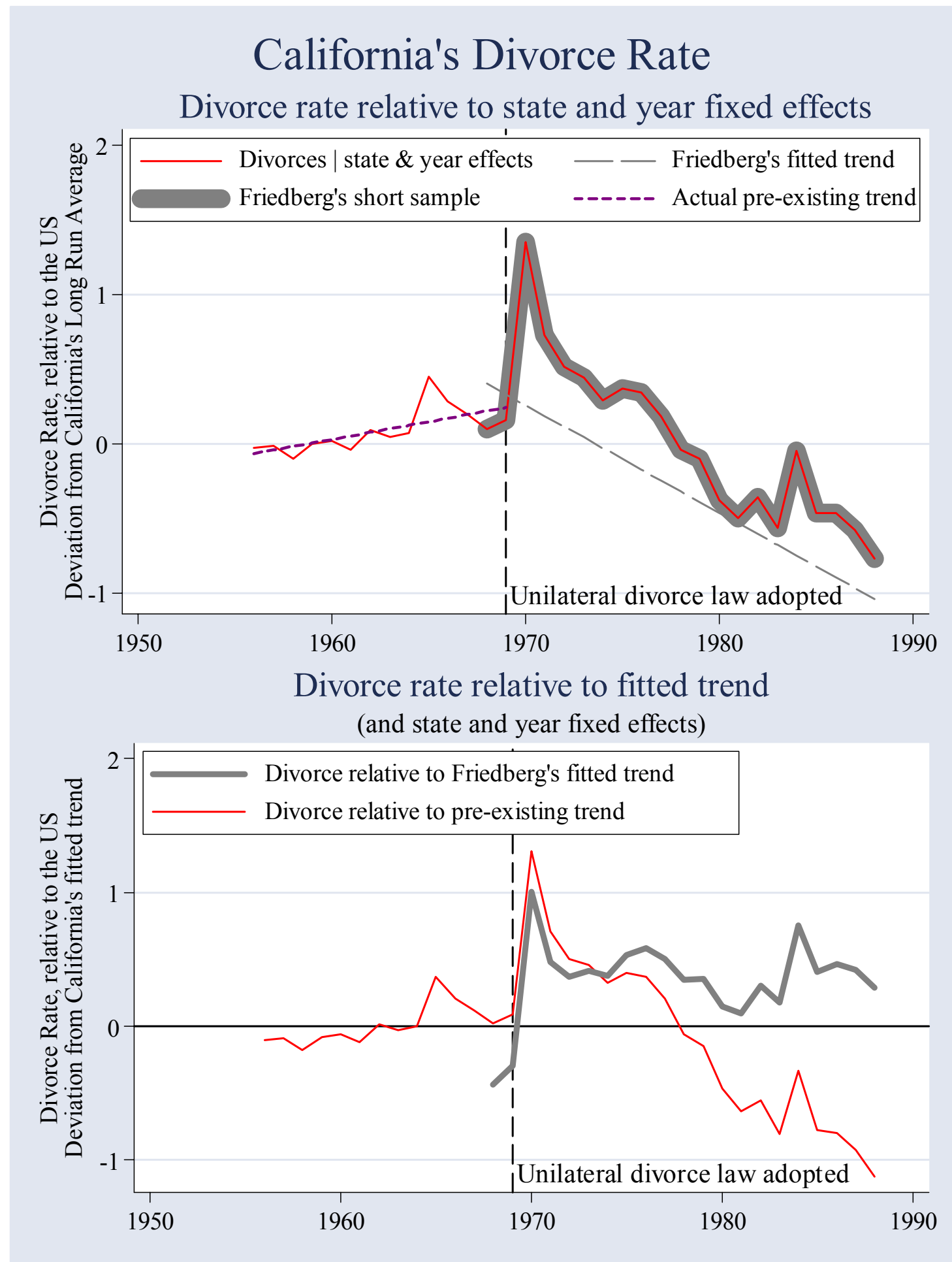




\section{Chart 5}

\section{Estimates of State-Specific Linear Time Trends}

Each point represents a regression-estimated state*time coefficient

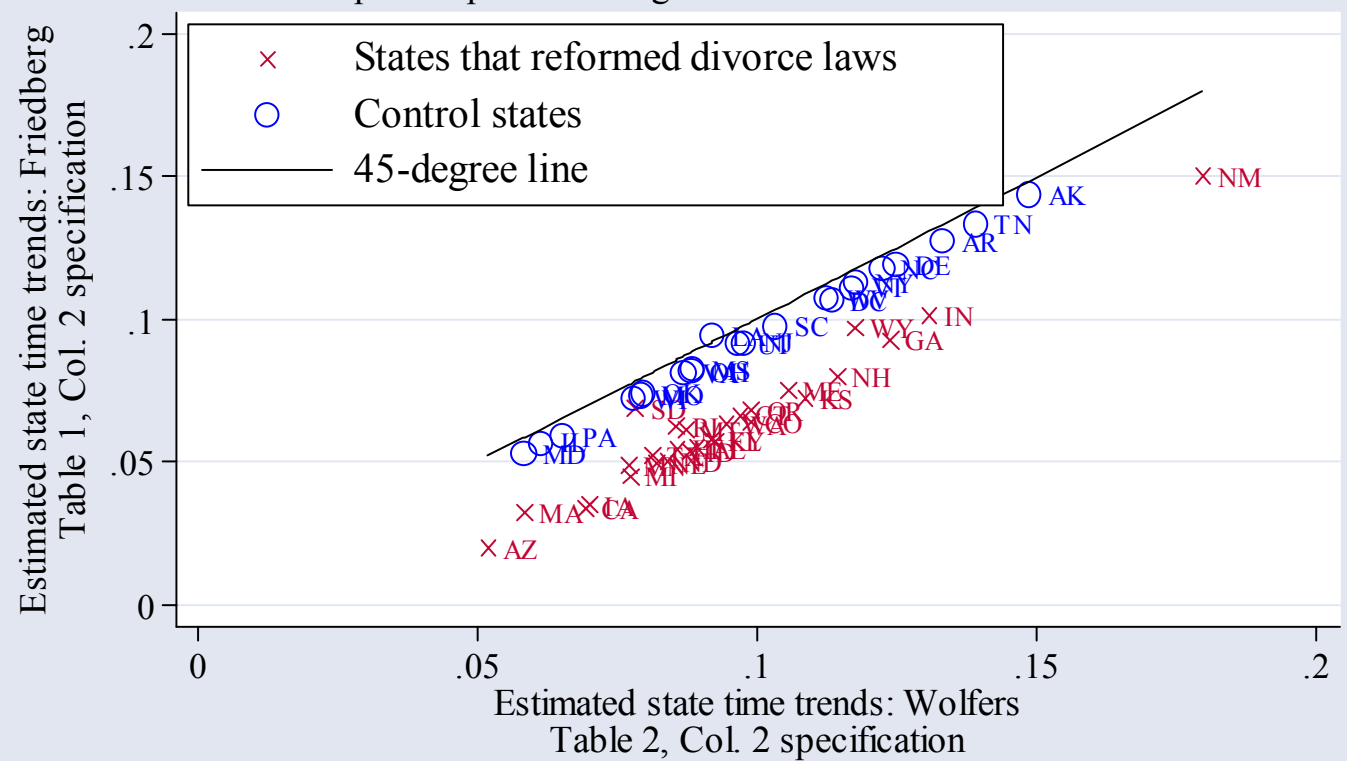

Population-weighted least squares regression; 1956-1988. Nevada off-scale $(-0.63,-0.60)$.

\section{Chart 6}

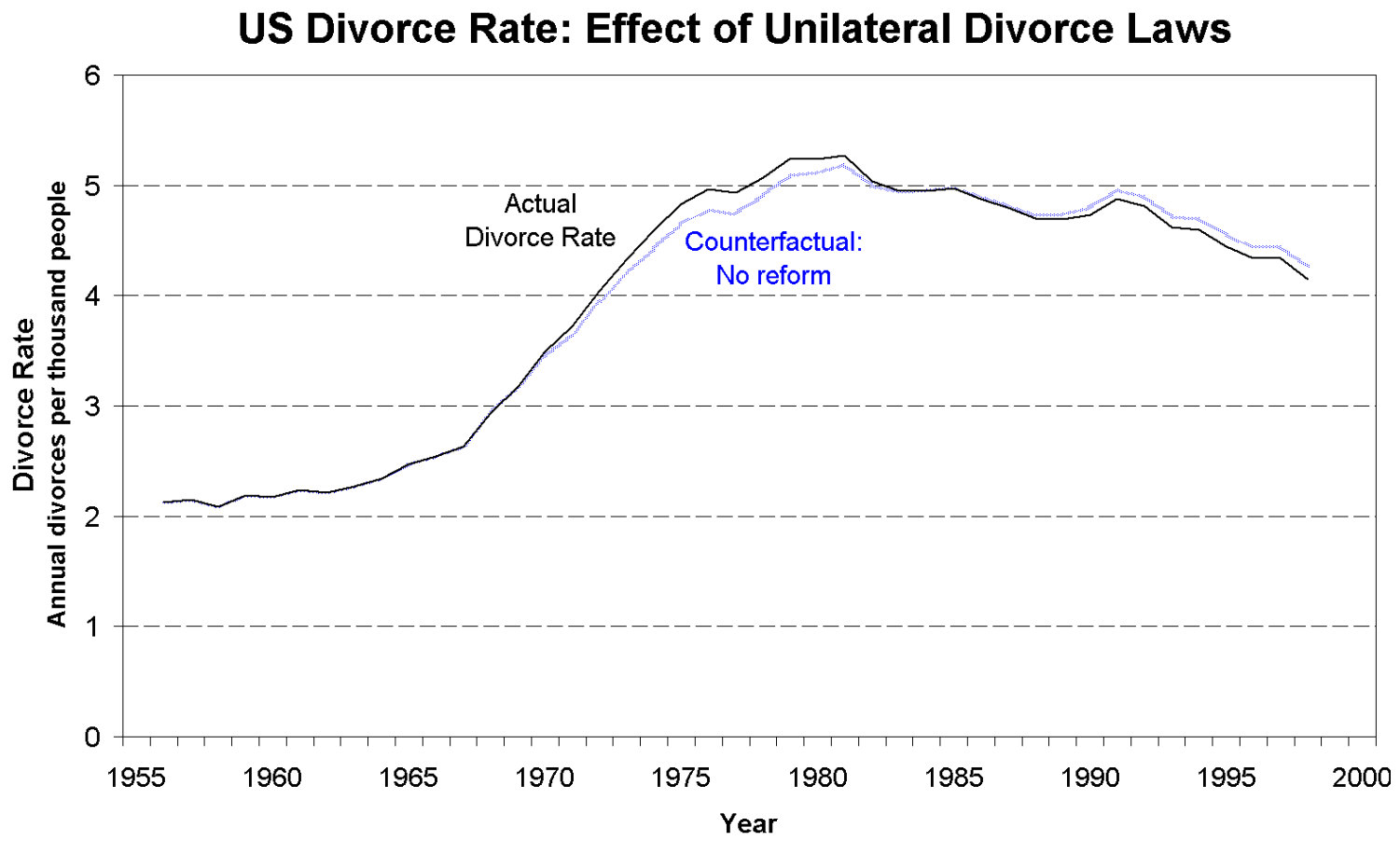

Notes: Chart is constructed based on the specification in column 3 of table 5 . 
Appendix A: Extending the Sample (Friedberg's specification)

\begin{tabular}{|c|c|c|c|}
\hline & $\begin{array}{c}\text { (1) } \\
\text { Basic Specification }\end{array}$ & $\begin{array}{c}(2) \\
\text { State-Specific Trends } \\
\text { Linear }\end{array}$ & $\begin{array}{c}\text { (3) } \\
\text { State-Specific } \\
\text { Trends } \\
\text { Quadratic }\end{array}$ \\
\hline \multicolumn{4}{|c|}{ Panel A: Friedberg's Sample: $1968-88(n=1043)$} \\
\hline Unilateral & $\begin{array}{c}.004 \\
\mathbf{( . 0 5 6 )}\end{array}$ & $\begin{array}{l}.447^{* * *} \\
(.050)\end{array}$ & $\begin{array}{l}.441^{* * * *} \\
(.055)\end{array}$ \\
\hline Year Effects & Yes, $\mathrm{F}=89^{* * *}$ & Yes, $\mathrm{F}=95^{* * *}$ & Yes, $\mathrm{F}=8.9^{* * *}$ \\
\hline State Effects & Yes, $\mathrm{F}=217^{* * *}$ & Yes, $\mathrm{F}=196^{* * *}$ & Yes, $\mathrm{F}=131^{* * *}$ \\
\hline State Trend, Linear & No & Yes, $\mathrm{F}=25^{* * *}$ & Yes, $\mathrm{F}=9.3^{* * *}$ \\
\hline $\begin{array}{l}\text { State Trend, } \\
\text { Quadratic }\end{array}$ & No & No & Yes, $\mathrm{F}=6.5^{* * *}$ \\
\hline Adjusted $\mathbf{R}^{2}$ & 0.946 & 0.976 & 0.982 \\
\hline
\end{tabular}

\begin{tabular}{|c|c|c|c|}
\hline \multicolumn{4}{|c|}{ Panel B: Wolfers' Sample: 1956-88 $(n=1631)$} \\
\hline Unilateral & $\begin{array}{l}.057 \\
(.061)\end{array}$ & $\begin{array}{c}0.496 \\
(0.056)\end{array}$ & $\begin{array}{l}0^{0.367}{ }^{* * * *} \\
(0.047)\end{array}$ \\
\hline Year Effects & Yes, $\mathrm{F}=90^{* * *}$ & Yes, $\mathrm{F}=58^{* * *}$ & Yes, $\mathrm{F}=74^{* * *}$ \\
\hline State Effects & Yes, $\mathrm{F}=190^{* * *}$ & Yes, $\mathrm{F}=629^{* * *}$ & Yes, $\mathrm{F}=229^{* * *}$ \\
\hline State Trend, Linear & No & Yes, $\mathrm{F}=75^{* * *}$ & Yes, $\mathrm{F}=101^{* * *}$ \\
\hline $\begin{array}{l}\text { State Trend, } \\
\text { Quadratic }\end{array}$ & No & No & Yes, $F=19^{* * *}$ \\
\hline Adjusted R ${ }^{2}$ & 0.979 & 0.994 & 0.996 \\
\hline
\end{tabular}

Panel A reproduces the results from Friedberg's 1968-88 sample. In Panel B, I extend Friedberg's sample back to 1956. Divorce data were hand-entered from annual editions of Vital Statistics. Extending the data on divorce laws was relatively simple. In two cases, Friedberg codes the adoption of unilateral divorce as pre-dating her sample - Alaska and Oklahoma.

Gruber codes these reforms as having occurred in 1935 and 1953 respectively, and hence I simply follow his coding.

These results are not particularly sensitive to extending the sample. At first glance, this is surprising - intuition suggests that the inclusion of a longer stretch of pre-intervention data offsets the bias issues described in the text. Simulations indicated that while adding centuries of preintervention data would indeed yield consistent estimates, the inclusion of another twelve years of data probably yields slightly more biased estimates. 